УДК 303.01

DOI $10.21661 / \mathrm{r}-555568$

А.А. Гревцева, О.Ю. Тарарыченкова

ОСНОВЫ ЭКОЛОГИЧЕСКОЙ ГРАМОТНОСТИ:

ПОДХОДЫ К ОБУЧЕНИЮ

Аннотация: в статье рассматривается проблема экологического образования и его влияния на формирование экологической культуры личности. Анализируются существующие подходы в области экологического образования, выявляются их достоинства и недостатки.

Ключевые слова: экологическая культура, экологическая грамотность, экологическое образование, обучение, подходы к обучению.

В условиях современной реальности влияние деятельности человека на окружающую среду значительно возросло, что и привело к глобальной экологической проблеме. Активное развитие техники и промышленного производства оказало негативное влияние и создало реальную угрозу всем живым организмам, населяющим нашу планету. Именно поэтому так важно формировать экологическую культуру, сознание и ответственность уже с младшего школьного возраста, когда закладываются основные представления о мире и психика очень восприимчива ко всему новому.

Актуальность проблем экологического образования в современном обществе возрастает. Это вызвано, прежде всего, необходимостью повышения экологической культуры человека, улучшения условий жизни человека на Земле, сохранения, восстановления и рационального использования природных богатств, низким уровнем восприятия человеком экологических проблем как лично значимых, недостаточно развитой у человека потребностью практического участия в природоохранной деятельности. В Федеральном законе РФ «Об охране окружающей среды» сказано, что овладение минимумом экологических знаний, необходимых для формирования экологической культуры граждан, во всех дошкольных, средних и высших учебных заведениях, независимо от профиля, обеспечивается обязательным преподаванием экологических знаний [1, С. 74]. 
В настоящее время нет единого определения понятия «экологическая грамотность». Рассматривая существующие трактовки, мы приходим к выводу, что под экологической грамотностью принято понимать запас экологических знаний и возможность применения этих знаний и навыков в повседневной жизни. Формированию экологической грамотности и служит образование в области экологической культуры. Только при достаточно высоком уровне экологической грамотности увеличивается продолжительность жизни населения, уменьшается число заболеваний и патологий; с помощью рационального природопользования происходит экономия и приумножение природных ресурсов, поэтому экологическое воспитание в настоящее время приобретает особую значимость в развитии любого города, региона, страны и мира [3]. Процесс формирование экологической грамотности должен осуществляться непрерывно, на всех этапах образования.

Современное экологическое образование - образование широкого профиля, включающее освоение комплекса гуманитарных и естественнонаучных знаний, направленное на формирование у обучающихся экосистемной познавательной модели, как основы развития экологического мышления, экологической грамотности, и ее творческое применение для накопления личного и совместного опыта рефлексивно-оценочной и проектной деятельности, ориентированной на ценности экологической этики и устойчивого развития. Это является условием становления экологической культуры гражданина, его ответственного отношения к соблюдению правовых и нравственных норм в области охраны окружающей среды, здоровья и безопасности жизни.

Экологическими знаниями должен обладать каждый человек, независимо от рода его деятельности. Однако, только приобретения экологических знаний недостаточно, важно выработать умение адекватно воспринимать экологические проблемы, способность понимать системы и процессы природы и окружающей среды, добиться осознания того, что каждый человек не только может, но и должен изменить экологическую ситуацию в стране. В этом и заключается суть экологической грамотности, которая, в свою очередь, является одной из основных 
целей экологического образования, состоящего в повышении уровня знаний об окружающей среде и связанных с ней проблемах, формировании и развитии навыков действовать индивидуально и коллективно в поисках решений современных проблем и предотвращении новых.

Цель формирования экологической грамотности состоит в том, чтобы сформировать ответственное отношение к окружающей среде. Оно выражается в активной деятельности, направленной на изучение окружающей природы, соблюдении нравственных и правовых принципов природопользования, охрану природы и пропаганду такого рода деятельности [6].

Для достижения поставленной цели необходимо проанализировать основные подходы к обучению школьников основам экологической грамотности.

Основная задача педагога в процессе экологического образования - сформировать у школьников представление о том, что представляет из себя окружающий мир, каковы взаимоотношения его составляющих и т. д. Акцент делается на отборе знаний о природе разной степени широты и систематизации с учетом возрастных особенностей детей.

Чаще в процессе обучения используют объяснительно-иллюстративную, репродуктивную группу методов, главным образом, показ и объяснение материала. Широкое использование этих методов объясняется тем, что они позволяют быстрее передать знания обучаемым, сформировать информированность. Однако, применение подобных методов имеет существенные недостатки: знания учащихся, как правило, недостаточно осознанны, мотивированны и действенны [8].

В рамках такого подхода используются следующие формы экологического образования: образовательные занятия, экскурсии, учебные экологические тропы, целевые прогулки, чтение познавательной литературы, просмотр познавательных фильмов природоведческого содержания и др.

Еще одна задача педагога - сформировать ценностное отношение к окружающему миру, положительное отношение детей к природе. Здесь важно сформировать такие знания и создать такие воспитательные ситуации, которые оказы- 
вают наибольшее влияние на формирование субъективного отношения к природе. Это наиболее сложный подход к экологическому обучению. В данной ситуации целесообразно использовать такие формы обучения как занятия экологоэтического, эколого-эстетического содержания, экологические праздники, викторины, решения кроссвордов, экологические КВНы, марафоны, конкурсы-аукционы, природоведческие дидактические игры, ролевые экологические игры, театральные этюды, эколого-психологические тренинги и т. п.

Формированию эстетического отношения детей к природе способствуют также театрализованные экологические игры, чтение художественной литературы о природе, сочинения на экологическую тематику, просмотр спектаклей, художественных фильмов природоведческого содержания, посещение художественных выставок, рассматривание картин о природе и т. п. Развитию ценностного отношения к природе способствует также выполнение учащимися практических работ оценочного характера, которые позволяют выработать у детей привычку правильно оценивать поведение людей в природе, выбрать линию поведения, соответствующую законам природы и общества. Знание и соблюдение учащимися правил поведения в природе во время экскурсий, походов свидетельствуют о степени сформированности их нравственного облика.

Технологический подход в экологическом образовании имеет направленность на формирование у детей экологически ориентированной, природоохранной деятельности. Здесь педагогу необходимо создать условия для овладения детьми соответствующими технологиями взаимодействия с природой, использования их в самостоятельной деятельности. При этом подходе преобладают следующие формы обучения: труд детей на природе (озеленение пришкольной территории), простейшие опыты с использованием природного материала, природоохранные акции, участие в лесном патрулировании, сбор плодов и семян луговых и древесно-кустарниковых растений, уборка валежника, подкормка птиц. Именно этот подход наиболее значим для формирования ответственного отношения к природе. 
Вне зависимости от выбранного подхода к обучению основам экологической грамотности к работе со школьниками необходимо подходить комплексно. В рамках комплексного подхода решаются задачи формирования экологической культуры личности, а именно: формирования и развития у детей элементарных экологических знаний, экологически ориентированного поведения и деятельности, познавательного, гуманного, эстетического отношения к природе.

Основой является, несомненно, урочная работа, вместе с тем должное внимание необходимо уделить разработке системы внеклассной работы с учащимися в области экологического образования. Внеклассная работа дает возможность решить целый ряд общепедагогических задач: индивидуальный подход к каждому ученику, развитие творческих способностей учащихся, формирование у них коммуникативных навыков и гражданской позиции. Активная внеклассная работа с детьми в области экологического образования способствует социализации учащихся, практической направленности образовательной деятельности школы, обеспечивает повышение рейтинга естественнонаучных знаний, увеличение познавательной активности школьников, формирование у них навыков исследовательской работы.

Комплексный, системный подход к изучению вопросов экологии с учетом специфики содержания определенного школьного курса, формирование экологической культуры личности служат гуманитаризации современного экологического образования.

Несмотря на определенные различия в подходах к реализации экологического образования, большинством специалистов признается необходимость включать рассмотрение экологических проблем практически во все учебные программы: от философии и социологии до географии и этики [2]. Экологическое образование имеет универсальный, междисциплинарный характер, поэтому оно должно стать неотъемлемой частью содержания всех уровней образования.

\section{Список литературь}

1. Об охране окружающей среды: Федеральный закон РФ от 10.01.2002 г. №7-Ф3 // Статья 74. Экологическое просвещение. 
2. Бакланова С.Л. Методика обучения экологии: учебное пособие / С.Л. Бакланова; Алтайская гос.академия обр-я им. В. М. Шукшина. - Бийск: ФГБОУ ВПО «АГАО», 2015. -180 c.

3. Головских Д.С. Формирование экологической грамотности на ступени высшего образования // Современные научные исследования и инновации. 2016. №3 [Электронный ресурс]. URL: https://web.snauka.ru/issues/2016/03/64928 (дата обращения: 23.04.2021).

4. Иванова Е.О. Компетентностный подход в соотношении со знаниевоориентированным и культурологическим. // Интернет-журнал «Эйдос». - 2007. 30 сентября. http:/www.eidos.ru/journal/2007/0930-23.htm. - В надзаг: Центр дистанционного образования «Эйдос», e-mail: list@eidos.ru.

5. Коурова С.И. Гуманитарный подход к изучению экологической составляющей в современном школьном образовании // Материалы XII Международной студенческой научной конференции «Студенческий научный форум» [Электронный $\quad$ ресурс]. - href=«https://scienceforum.ru/2020/article/2018021647»>https://scienceforum.ru/202 0/article/2018021647</a> (дата обращения: 01.05.2021).

6. Нестерова И.А. Экологическая грамотность // Энциклопедия Нестеровых [Электронный ресурс]. http://odiplom.ru/lab/ekologicheskaya-gramotnost.html.

7. Савенкова Л.Г. Гуманитаризация современного образования в условиях социокультурного пространства региона / EDUSTRONG, 2020. [Электронный pecypc]. - Режим доступа: http://www.edustrong.ru - 13. 01. 2020.

8. Стрекаловская М.М. Педагогические подходы в экологическом образовании детей дошкольного возраста / М.М. Стрекаловская, Т.М. Дарханова // Педагогический журнал. - 2016. - №2 . - С. 64-72.

Гревцева Анна Анатольевна - канд. филос. наук, доцент, ФГБОУ ВО «ОГУ им. И.С. Тургенева», Россия, Орел. 
Тарарыченкова Оксана Юрьевна - магистрант, ФГБОУ ВО «ОГУ им. И.С. Тургенева», Россия, Орел. 